Article

\title{
Azaphilones from the Red Sea Fungus Aspergillus falconensis
}

\author{
Dina H. El-Kashef ${ }^{1,2}{ }^{\oplus}$, Fadia S. Youssef ${ }^{1,3}{ }^{\circledR}$, Rudolf Hartmann ${ }^{4}$, Tim-Oliver Knedel ${ }^{5}$, \\ Christoph Janiak ${ }^{5}\left(\mathbb{D}\right.$, Wenhan Lin ${ }^{6}$ D , Irene Reimche ${ }^{7}$, Nicole Teusch ${ }^{7} \mathbb{D}$, Zhen Liu ${ }^{1, *(\mathbb{D})}$ and \\ Peter Proksch 1,8,*
}

1 Institute of Pharmaceutical Biology and Biotechnology, Heinrich-Heine-University Duesseldorf, 40225 Duesseldorf, Germany; dina.elkashef@mu.edu.eg (D.H.E.-K.); fadiayoussef@pharma.asu.edu.eg (F.S.Y.)

2 Department of Pharmacognosy, Faculty of Pharmacy, Minia University, 61519 Minia, Egypt

3 Department of Pharmacognosy, Faculty of Pharmacy, Ain Shams University, Abbassia, 11566 Cairo, Egypt

4 Institute of Complex Systems: Strukturbiochemie, Forschungszentrum Jülich GmbH, ICS-6, 52425 Jülich, Germany; r.hartmann@fz-juelich.de

5 Institut für Anorganische Chemie und Strukturchemie, Heinrich-Heine-Universität Düsseldorf, 40225 Düsseldorf, Germany; tim-oliver.knedel@hhu.de (T.-O.K.); janiak@uni-duesseldorf.de (C.J.)

6 State Key Laboratory of Natural and Biomimetic Drugs, Peking University, Beijing 100191, China; whlin@bjmu.edu.cn

7 Department of Biomedical Sciences, Institute of Health Research and Education, University of Osnabrück, 49074 Osnabrück, Germany; irene.reimche@uni-osnabrueck.de (I.R.); nicole.teusch@uni-osnabrueck.de (N.T.)

8 Hubei Key Laboratory of Natural Products Research and Development, College of Biological and Pharmaceutical Sciences, China Three Gorges University, Yichang 443002, China

* Correspondence: zhenfeizi0@sina.com (Z.L.); proksch@uni-duesseldorf.de (P.P.); Tel.: +49-211-81-14163 (Z.L. \& P.P.)

Received: 4 March 2020; Accepted: 5 April 2020; Published: 10 April 2020

\begin{abstract}
The marine-derived fungus Aspergillus falconensis, isolated from sediment collected from the Canyon at Dahab, Red Sea, yielded two new chlorinated azaphilones, falconensins $\mathrm{O}$ and $\mathrm{P}$ (1 and 2) in addition to four known azaphilone derivatives (3-6) following fermentation of the fungus on solid rice medium containing 3.5\% NaCl. Replacing $\mathrm{NaCl}$ with $3.5 \% \mathrm{NaBr}$ induced accumulation of three additional new azaphilones, falconensins Q-S (7-9) including two brominated derivatives (7 and 8) together with three known analogues (10-12). The structures of the new compounds were elucidated by 1D and 2D NMR spectroscopy and HRESIMS data as well as by comparison with the literature. The absolute configuration of the azaphilone derivatives was established based on single-crystal X-ray diffraction analysis of 5, comparison of NMR data and optical rotations as well as on biogenetic considerations. Compounds 1, 3-9, and 11 showed NF-кB inhibitory activity against the triple negative breast cancer cell line MDA-MB-231 with $\mathrm{IC}_{50}$ values ranging from 11.9 to $72.0 \mu \mathrm{M}$.
\end{abstract}

Keywords: Aspergillus falconensis; OSMAC; azaphilones; X-ray diffraction; NF-кB inhibition

\section{Introduction}

In the last two decades, marine-derived fungi have gained considerable attention for drug discovery due to their ability to produce a vast diversity of bioactive secondary metabolites [1]. Up until today, hundreds of secondary metabolites have been characterized from marine-derived fungi exhibiting promising biological and pharmacological properties [2,3]. In particular, the diketopiperazine alkaloid halimide, obtained from a marine-derived fungus Aspergillus sp., was the lead structure for the putative 
anticancer drug plinabulin, which has entered Phase III of clinical trials against non-small cell lung cancer [4-6]. Interestingly, genomic sequencing revealed that under conventional culture conditions, many biosynthetic fungal gene clusters remain silent and transcriptionally suppressed $[7,8]$. Changing the cultivation conditions of fungi may activate silent biosynthetic gene clusters and eventually lead to either upregulation of constitutively present compounds or accumulation of new natural products [9]. The OSMAC (One Strain MAny Compounds) approach, first described by Zeeck et al. [10], represents one of the strategies which triggers diversification of the metabolic profile of fungi by altering the cultivation conditions. Fungi of the genus Aspergillus are rich sources of numerous bioactive secondary metabolites [11-13]. Consequently, as a part of our ongoing research on marine-derived fungi [14-16], we have investigated the fungus Aspergillus falconensis (formerly known as Emericella falconensis [17]) that was isolated from sea sediment collected at a depth of $25 \mathrm{~m}$ from the Canyon at Dahab, Red Sea, Egypt. The previously isolated soil-derived fungus, Emericella falconesis, is known as a producer of anti-inflammatory azaphilone derivatives [18-21]. Herein, we report the isolation, structure elucidation, and bioactivity of azaphilones obtained from $A$. falconensis following fermentation of the fungus on solid rice medium that contained either $3.5 \% \mathrm{NaCl}$ or $3.5 \% \mathrm{NaBr}$. Following this approach, we were able to obtain two new chlorinated azaphilones ( $\mathbf{1}$ and $\mathbf{2}$ ) together with four known azaphilone derivatives (3-6) when the fungus was cultivated in the presence of $\mathrm{NaCl}$ and three additional new azaphilone derivatives (7-9) including two brominated analogues (7 and 8) in addition to three known derivatives (10-12) in the presence of NaBr. Compounds 1, 3-9, and 11 were examined with regard to their nuclear factor kappa $\mathrm{B}(\mathrm{NF}-\mathrm{KB})$ inhibitory activity in the triple negative breast cancer (TNBC) cell line MDA-MB-231. In TNBC, constitutive activation of the proinflammatory NF- $\mathrm{KB}$ is associated with tumor aggressiveness [22]. All tested compounds revealed inhibition of NF- $\mathrm{kB}$ signaling with $\mathrm{IC}_{50}$ values at two-digit micromolar concentrations.

\section{Results and Discussion}

After fermentation of $A$. falconensis on solid rice medium containing $3.5 \% \mathrm{NaCl}$ (similar to the salinity of sea water), chromatographic separation of the EtOAc extract of the fungus yielded two new chlorinated azaphilone derivatives (1-2). In addition, four known azaphilones (3-6) were identified including falconensins A (3) [18], M (4) [23], N (5) [23], and H (6) [19] by comparison of their spectroscopic data with the literature.

Compound 1 was isolated as a yellow oil. Its HRESIMS analysis showed an isotope pattern characteristic for two chlorine atoms in the molecule at $m / z$ 511/513/515 (9:6:1), corresponding to the molecular formula $\mathrm{C}_{24} \mathrm{H}_{24} \mathrm{Cl}_{2} \mathrm{O}_{8}$ with 12 degrees of unsaturation. The UV pattern and NMR data of 1 (Tables 1 and 2) were similar to those of the co-isolated known falconensin M (4), which was previously reported from Emericella falconensis [23], suggesting 1 to be an azaphilone derivative [24]. However, the ${ }^{1} \mathrm{H}$ NMR spectrum of 1 displayed the signal of an additional methyl group at $\delta_{\mathrm{H}} 2.07$ (s) when compared to 4 . The Heteronuclear Multiple Bond Correlation (HMBC) correlations from the protons of this additional methyl and $\mathrm{H}-8$ to a carbonyl carbon at $\delta_{\mathrm{C}} 170.0$ together with the obvious deshielded chemical shift of $\mathrm{H}-8\left(\delta_{\mathrm{H}} 6.11\right)$ indicated the replacement of the hydroxy group by an acetoxy group at C-8 in 1 . Detailed analysis of the 2D NMR spectra of 1 indicated that the remaining substructure of 1 was identical to that of 4 . The large values of ${ }^{3} J_{\mathrm{H}-8, \mathrm{H}-8 \mathrm{a}}(10.7 \mathrm{~Hz})$ and ${ }^{3} \mathrm{~J}_{\mathrm{H}-1 \mathrm{~b}, \mathrm{H}-8 \mathrm{a}}(13.0 \mathrm{~Hz})$ and the small value of ${ }^{3} J_{\mathrm{H}-1 \mathrm{a}, \mathrm{H}-8 \mathrm{a}}(5.0 \mathrm{~Hz})$ obtained from the ${ }^{1} \mathrm{H}$ NMR spectrum of $\mathbf{1}$, indicated trans-diaxial orientation between $\mathrm{H}-8 \mathrm{a}\left(\delta_{\mathrm{H}} 2.98\right)$ and $\mathrm{H}-8$ and between $\mathrm{H}-8 \mathrm{a}$ and $\mathrm{H}-1 \mathrm{~b}\left(\delta_{\mathrm{H}} 3.96\right)$ and cis-orientation between $\mathrm{H}-8 \mathrm{a}$ and $\mathrm{H}-1 \mathrm{a}\left(\delta_{\mathrm{H}} 4.34\right)$. The NOE correlations from $\mathrm{H}-8 \mathrm{a}$ to $\mathrm{H}-1 \mathrm{a}$ and Me-9 $\left(\delta_{\mathrm{H}} 1.56\right)$ as well as between $\mathrm{H}-8$ and $\mathrm{H}-1 \mathrm{~b}$ confirmed that $\mathrm{H}-1 \mathrm{a}, \mathrm{H}-8 \mathrm{a}$ and Me-9 were on the same side of the ring ( $\alpha$-oriented) whereas $\mathrm{H}-1 \mathrm{~b}$ and $\mathrm{H}-8$ were on the opposite side ( $\beta$-oriented). Thus, compound $\mathbf{1}$ was elucidated as 8-O-acetyl analogue of 4 , representing a new falconensin derivative, for which the trivial name falconensin $\mathrm{O}$ is proposed. Incubation of putative precursors of $\mathbf{1}$ such as $\mathbf{4}$ in EtOAc over three days failed to generate the corresponding acetates, thus ruling out the possibility that the acetylated azaphilones isolated in this study are artefacts generated during chromatographic workup. 
Table $1 .{ }^{13} \mathrm{C}$ NMR data of compounds $\mathbf{1}, \mathbf{2}, \mathbf{7}, \mathbf{8}$, and 9 in $\mathrm{CDCl}_{3}$.

\begin{tabular}{|c|c|c|c|c|c|}
\hline No. & $1^{a, c}$ & $2^{a, c}$ & $7^{b}$ & $8^{a, c}$ & $9^{b}$ \\
\hline 1 & $67.8, \mathrm{CH}_{2}$ & $68.2, \mathrm{CH}_{2}$ & $68.5, \mathrm{CH}_{2}$ & $68.4, \mathrm{CH}_{2}$ & $68.0, \mathrm{CH}_{2}$ \\
\hline 3 & $160.2, \mathrm{C}$ & $168.2, \mathrm{C}$ & $160.5, \mathrm{C}$ & $160.2, \mathrm{C}$ & $160.2, \mathrm{C}$ \\
\hline 4 & $102.4, \mathrm{CH}$ & $100.9, \mathrm{CH}$ & $102.8, \mathrm{CH}$ & $102.6 \mathrm{CH}$ & $102.8, \mathrm{CH}$ \\
\hline $4 a$ & $149.4, \mathrm{C}$ & $149.2, \mathrm{C}$ & $150.3, \mathrm{C}$ & $149.9, \mathrm{C}$ & $148.9, \mathrm{C}$ \\
\hline 5 & $116.6, \mathrm{CH}$ & $115.7, \mathrm{CH}$ & $116.6, \mathrm{CH}$ & $116.6, \mathrm{CH}$ & $117.1, \mathrm{CH}$ \\
\hline 6 & $192.3, \mathrm{C}$ & $192.7, \mathrm{C}$ & $193.8, \mathrm{C}$ & $193.4, \mathrm{C}$ & $193.3, \mathrm{C}$ \\
\hline 7 & $83.4, \mathrm{C}$ & $83.4, \mathrm{C}$ & $85.6, \mathrm{C}$ & $85.4, \mathrm{C}$ & $82.5, \mathrm{C}$ \\
\hline 8 & $70.1, \mathrm{CH}$ & $70.4, \mathrm{CH}$ & $69.8, \mathrm{CH}$ & $69.7, \mathrm{CH}$ & $70.7, \mathrm{CH}$ \\
\hline $8 a$ & $38.1, \mathrm{CH}$ & $38.0, \mathrm{CH}$ & $37.8, \mathrm{CH}$ & $37.5, \mathrm{CH}$ & $38.2, \mathrm{CH}$ \\
\hline 9 & $17.9, \mathrm{CH}_{3}$ & $18.2, \mathrm{CH}_{3}$ & $16.8, \mathrm{CH}_{3}$ & $16.6, \mathrm{CH}_{3}$ & $18.2, \mathrm{CH}_{3}$ \\
\hline 10 & $124.9, \mathrm{CH}$ & $36.4, \mathrm{CH}_{2}$ & $125.4, \mathrm{CH}$ & $125.3, \mathrm{CH}$ & $125.2, \mathrm{CH}$ \\
\hline 11 & $134.1, \mathrm{CH}$ & $20.0, \mathrm{CH}_{2}$ & $133.9, \mathrm{CH}$ & $133.6, \mathrm{CH}$ & $133.9, \mathrm{CH}$ \\
\hline 12 & $18.2, \mathrm{CH}_{3}$ & $13.6, \mathrm{CH}_{3}$ & $18.4, \mathrm{CH}_{3}$ & $18.2, \mathrm{CH}_{3}$ & $18.4, \mathrm{CH}_{3}$ \\
\hline $1^{\prime}$ & $164.3, \mathrm{C}$ & $164.4, \mathrm{C}$ & 165.3, C & $164.9, \mathrm{C}$ & $166.2, \mathrm{C}$ \\
\hline $2^{\prime}$ & 122.2, C & 122.3, C & $117.4, \mathrm{C}$ & 117.2, C & $115.5, \mathrm{C}$ \\
\hline $3^{\prime}$ & $152.8, \mathrm{C}$ & $152.9, \mathrm{C}$ & $156.2, \mathrm{C}$ & 157.3, C & $159.0, \mathrm{C}$ \\
\hline $4^{\prime}$ & $112.9, \mathrm{C}$ & $112.8, \mathrm{C}$ & $97.1, \mathrm{CH}$ & $93.8, \mathrm{CH}$ & $96.9, \mathrm{CH}$ \\
\hline $5^{\prime}$ & $149.2, \mathrm{C}$ & $149.8, \mathrm{C}$ & 154.0, C & $155.8, \mathrm{C}$ & 157.6, C \\
\hline $6^{\prime}$ & 117.0, C & 117.1, C & 105.3, C & 106.6, C & $109.2, \mathrm{CH}$ \\
\hline $7^{\prime}$ & 134.3, C & 134.5, C & $137.4, \mathrm{C}$ & $138.1, \mathrm{C}$ & $140.0, \mathrm{C}$ \\
\hline $8^{\prime}$ & $16.9, \mathrm{CH}_{3}$ & $17.1, \mathrm{CH}_{3}$ & $20.2, \mathrm{CH}_{3}$ & $20.1, \mathrm{CH}_{3}$ & 19.6, $\mathrm{CH}_{3}$ \\
\hline \multirow[t]{2}{*}{ 8-OAc } & $170.0, \mathrm{C}$ & $170.1, \mathrm{C}$ & & & $169.7, \mathrm{C}$ \\
\hline & $20.5, \mathrm{CH}_{3}$ & $20.8, \mathrm{CH}_{3}$ & & & $20.8, \mathrm{CH}_{3}$ \\
\hline $3^{\prime}-\mathrm{OMe}$ & $62.4, \mathrm{CH}_{3}$ & $62.6, \mathrm{CH}_{3}$ & $56.5, \mathrm{CH}_{3}$ & $56.3{ }^{\mathrm{d}} \mathrm{CH}_{3}$ & $56.0, \mathrm{CH}_{3}$ \\
\hline $5^{\prime}-\mathrm{OMe}$ & & & & $56.4{ }^{\mathrm{d}} \mathrm{CH}_{3}$ & \\
\hline
\end{tabular}

${ }^{\text {a }}$ Measured at $150 \mathrm{MHz} ;{ }^{\mathrm{b}}$ Measured at $175 \mathrm{MHz} ;{ }^{\mathrm{c}}$ Data extracted from the HSQC (Heteronuclear Single Quantum Coherence) and $\mathrm{HMBC}$ spectra; ${ }^{\mathrm{d}}$ interchangeable.

Table 2. ${ }^{1} \mathrm{H}$ NMR data of compounds $1,2,7,8$, and 9 in $\mathrm{CDCl}_{3}$.

\begin{tabular}{|c|c|c|c|c|c|}
\hline No. & $1^{a}$ & $2^{a}$ & $7^{b}$ & $8^{a}$ & $9^{b}$ \\
\hline 1 & $\begin{array}{l}4.34 \text {, dd }(11.0,5.0) \\
3.96 \text {, dd }(13.0,11.0)\end{array}$ & $\begin{array}{l}4.29 \text {, dd }(11.0,5.1) \\
3.93 \text {, dd }(13.2,11.0)\end{array}$ & $\begin{array}{l}4.77 \text {, dd }(10.5,5.1) \\
3.84 \text {, dd }(13.0,10.5)\end{array}$ & $\begin{array}{l}4.77 \text {, dd }(10.6,5.0) \text {; } \\
\text { 3.84, dd }(13.0,10.6)\end{array}$ & $\begin{array}{r}4.32 \text {, dd }(10.8,5.0) \\
3.93, \text { dd }(13.0,10.8)\end{array}$ \\
\hline 4 & $5.59, \mathrm{~s}$ & $5.53, \mathrm{~s}$ & $5.56, \mathrm{~s}$ & $5.57, \mathrm{~s}$ & $5.57, \mathrm{~s}$ \\
\hline 5 & $5.86, \mathrm{~d}(1.7)$ & $5.79, \mathrm{~d}(1.9)$ & $5.80, \mathrm{~d}(1.6)$ & $5.80, \mathrm{~d}(1.8)$ & $5.85, \mathrm{~d}(1.9)$ \\
\hline 8 & 6.11, d (10.7) & $6.09, \mathrm{~d}(10.7)$ & $4.74, \mathrm{~d}(10.7)$ & $4.75, \mathrm{~d}(10.7)$ & $6.11, d(10.7)$ \\
\hline $8 a$ & $\begin{array}{c}\text { 2.98, dddd (13.0, } \\
10.7,5.0,1.7)\end{array}$ & $\begin{array}{c}\text { 2.94, dddd (13.2, } \\
10.7,5.1,1.9)\end{array}$ & $\begin{array}{c}\text { 2.88, dddd (13.0, } \\
10.7,5.1,1.6)\end{array}$ & $\begin{array}{c}\text { 2.88, dddd (13.0, } \\
10.7,5.0,1.8)\end{array}$ & $\begin{array}{c}\text { 2.96, dddd (13.0, } \\
10.7,5.0,1.9)\end{array}$ \\
\hline 9 & $1.56, \mathrm{~s}$ & $1.56, \mathrm{~s}$ & $1.47, \mathrm{~s}$ & $1.47, \mathrm{~s}$ & $1.54, \mathrm{~s}$ \\
\hline 10 & $5.91, \mathrm{dq}(15.4,1.3)$ & $2.20, \mathrm{~m}$ & $5.90, \mathrm{dq}(15.4,1.4)$ & $5.90, \mathrm{dd}(15.4,1.5)$ & $5.90, \mathrm{dd}(15.3,1.6)$ \\
\hline 11 & $6.45, \mathrm{dq}(15.4,7.0)$ & $1.58, \mathrm{~m}$ & $6.47, \mathrm{dq}(15.4,7.0)$ & 6.46, dd $(15.4,7.0)$ & 6.42, dd $(15.3,7.0)$ \\
\hline 12 & $1.88, \mathrm{dd}(7.0,1.3)$ & $0.94, \mathrm{t}(7.4)$ & $1.87, \mathrm{dd}(7.0,1.4)$ & $1.88, \mathrm{dd}(7.0,1.5)$ & $1.87, \mathrm{dd}(7.0,1.6)$ \\
\hline $4^{\prime}$ & & & $6.52, \mathrm{~s}$ & $6.38, \mathrm{~s}$ & $6.23, \mathrm{~s}$ \\
\hline $6^{\prime}$ & & & & & $6.22, \mathrm{~s}$ \\
\hline $8^{\prime}$ & $2.50, \mathrm{~s}$ & $2.50, \mathrm{~s}$ & $2.48, \mathrm{~s}$ & $2.51, \mathrm{~s}$ & $2.39, \mathrm{~s}$ \\
\hline 8-OAc & $2.17, \mathrm{~s}$ & $2.16, \mathrm{~s}$ & & & $2.15, \mathrm{~s}$ \\
\hline $3^{\prime}-\mathrm{OMe}$ & $3.83, \mathrm{~s}$ & $3.83, \mathrm{~s}$ & $3.83, \mathrm{~s}$ & $3.92,{ }^{\mathrm{c}} \mathrm{s}$ & $3.74, \mathrm{~s}$ \\
\hline $5^{\prime}-\mathrm{OH}$ & $6.04, \mathrm{~s}$ & $6.04, \mathrm{~s}$ & & & \\
\hline 5'-OMe & & & & $3.89,{ }^{\mathrm{c}} \mathrm{s}$ & \\
\hline
\end{tabular}

${ }^{\text {a }}$ Measured at $600 \mathrm{MHz} ;{ }^{\mathrm{b}}$ Measured at $700 \mathrm{MHz} ;{ }^{\mathrm{c}}$ interchangeable.

The molecular formula of compound 2 was deduced as $\mathrm{C}_{24} \mathrm{H}_{26} \mathrm{Cl}_{2} \mathrm{O}_{8}$, containing two additional protons when compared to 1 . Investigation of the ${ }^{1} \mathrm{H}$ and ${ }^{13} \mathrm{C}$ NMR data of 2 (Tables 1 and 2) demonstrated the close structural similarity between $\mathbf{1}$ and $\mathbf{2}$ except for signals of the side chain at C-3. In particular, the resonances for the olefinic methine protons at $\delta_{\mathrm{H}} 5.91(\mathrm{H}-10)$ and $6.45(\mathrm{H}-11)$ of 1 were replaced by two methylene groups at $\delta_{\mathrm{H}} 2.20\left(\mathrm{H}_{2}-10\right)$ and $1.58\left(\mathrm{H}_{2}-11\right)$ in 2 . The COSY correlations between $\mathrm{H}_{2}-10 / \mathrm{H}_{2}-11 / \mathrm{Me}-12$ together with the $\mathrm{HMBC}$ correlations from $\mathrm{H}_{2}-11$ to $\mathrm{C}-3\left(\delta_{\mathrm{C}} 168.2\right)$ and 
from $\mathrm{H}_{2}-10$ to $\mathrm{C}-3$ and $\mathrm{C}-4\left(\delta_{\mathrm{C}} 100.9\right)$ confirmed the attachment of a $n$-propyl moiety at $\mathrm{C}-3$ in 2 . The remaining substructure of 2 was determined to be identical to that of 1 by comparison of the 2D NMR data of $\mathbf{1}$ and 2 . The similar coupling constants and NOE relationships between $\mathbf{1}$ and $\mathbf{2}$ indicated that both share the same relative configuration.

When $3.5 \% \mathrm{NaCl}$ as a constituent of the rice medium was replaced with $3.5 \% \mathrm{NaBr}$, a profound change in the metabolic profile of the fungus was observed. In total, two new brominated azaphilone derivatives (7 and 8), one new non-halogenated azaphilone (9), in addition to the known falconensins $\mathrm{K}(\mathbf{1 0})$ [23] and I (11) [23] were obtained.

The ${ }^{1} \mathrm{H}$ and ${ }^{13} \mathrm{C}$ NMR spectra of 7 (Tables 1 and 2) were comparable to those of the co-isolated known compound, falconensin K (10) [23]. The HRESIMS data of 7 established the molecular formula $\mathrm{C}_{22} \mathrm{H}_{23} \mathrm{BrO}_{7}$, differing from that of $\mathbf{1 0}$ by the replacement of the chlorine with a bromine atom. The HMBC correlations from Me- $8^{\prime}\left(\delta_{\mathrm{H}} 2.48\right)$ to C-2' $\left(\delta_{\mathrm{C}} 117.4\right), \mathrm{C}-6^{\prime}\left(\delta_{\mathrm{C}} 105.3\right)$, and $\mathrm{C}-7^{\prime}\left(\delta_{\mathrm{C}} 137.4\right)$, from $\mathrm{H}-4^{\prime}$ to $\mathrm{C}-2^{\prime}, \mathrm{C}-6^{\prime}, \mathrm{C}-3^{\prime}\left(\delta_{\mathrm{C}} 156.2\right)$, and $\mathrm{C}-4^{\prime}\left(\delta_{\mathrm{C}} 154.0\right)$, from $3^{\prime}-\mathrm{OMe}\left(\delta_{\mathrm{H}} 3.83\right)$ to $\mathrm{C}-3^{\prime}$ together with the NOE correlation between $3^{\prime}$-OMe and Me-9 $\left(\delta_{\mathrm{H}} 1.47\right)$ indicated the position of the bromine atom at C- $6^{\prime}$ in 7 . The remaining azaphilone core structure including the relative configuration of 7 was confirmed to be identical to that of $\mathbf{1 0}$ after further inspection of the 2D NMR spectra of $\mathbf{7}$. Thus, the structure of $\mathbf{7}$ was elucidated as shown (Figure 1), and the trivial name falconensin $Q$ is proposed for this compound.<smiles>CC=CC1=CC2=CC(=O)[C@](C)(OC(=O)c3c(Br)c(Cl)c(O)c(Cl)c3OC)[C@@H](O)[C@@H]2CO1</smiles><smiles>[R20]c1c(Cl)c(C)c(C(=O)O[C@]2(C)C(=O)C=C3C=C(/C=C/C)OC[C@H]3[C@H]2O)c(OC)c1Cl</smiles><smiles>[R20]C=[R][H]</smiles><smiles>[R]C1[C@H]2COC(CCC)=CC2=CC(=O)[C@]1(C)OC(=O)c1c(C)c(Cl)c(O)c(Cl)c1OC</smiles><smiles>C/C=C/C1=CC2=CC(=O)[C@@](C)(OC(=O)c3c(C)c(Cl)c(O)c(Cl)c3OC)C(=O)C2=CO1</smiles>

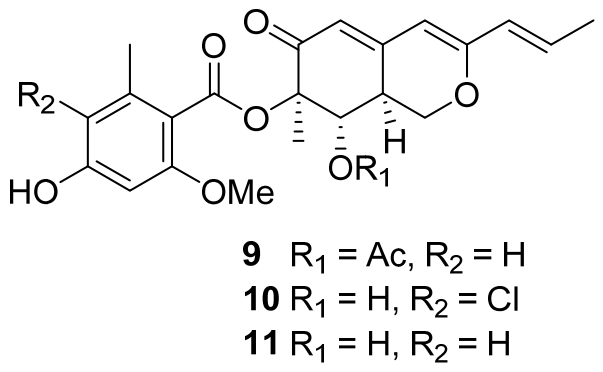

Figure 1. Structures of azaphilones isolated from A. falconensis.

Falconensin $\mathrm{R}(8)$ was isolated as a yellow oil. Its molecular formula was determined as $\mathrm{C}_{23} \mathrm{H}_{25} \mathrm{BrO}_{7}$ by HRESIMS, containing an additional methyl group when compared to 7. The NMR data of 8 (Tables 1 and 2) were similar to those of 7 except for the appearance of two methoxy groups at $\delta_{\mathrm{C}} 56.4$ and 56.3 , and at $\delta_{\mathrm{H}} 3.89\left(5^{\prime}-\mathrm{OMe}\right)$ and $3.92\left(3^{\prime}-\mathrm{OMe}\right)$ instead of one methoxy group in 7 . The location of the additional methoxy group at $\mathrm{C}-5^{\prime}$ in 8 was confirmed by the HMBC correlations from $3^{\prime}$-OMe to C-3' $\left(\delta_{\mathrm{C}} 157.3\right)$, from $5^{\prime}-\mathrm{OMe}$ to $\mathrm{C}-5^{\prime}\left(\delta_{\mathrm{C}} 155.8\right)$, and from $\mathrm{H}-4^{\prime}$ to $\mathrm{C}-2^{\prime}\left(\delta_{\mathrm{C}} 117.2\right), \mathrm{C}-6^{\prime}\left(\delta_{\mathrm{C}} 106.6\right), \mathrm{C}-3^{\prime}$ and $\mathrm{C}-5^{\prime}$, as well as based on the NOE correlations from $\mathrm{H}-4^{\prime}$ to $3^{\prime}$-OMe and $5^{\prime}$-OMe. 
The molecular formula of 9 was determined as $\mathrm{C}_{24} \mathrm{H}_{26} \mathrm{O}_{8}$ by HRESIMS, indicating 42 amu more than that of the co-isolated known falconensin I (11) $\left(\mathrm{C}_{22} \mathrm{H}_{24} \mathrm{O}_{7}\right)$ [23]. Comparison of the ${ }^{1} \mathrm{H}$ and ${ }^{13} \mathrm{C}$ NMR spectra revealed that the structure of 9 was closely related to that of 11, except for the appearance of an additional acetoxy group at $\delta_{\mathrm{H}} 2.15$ and $\delta_{\mathrm{C}} 20.8$ and $169.7 \mathrm{in}$ 9. The location of this additional acetoxy group at C-8 was confirmed by the COSY correlations between $\mathrm{H}-1 \mathrm{ab} / \mathrm{H}-8 \mathrm{a} / \mathrm{H}-8$ and the HMBC correlations from H-8 to the carbon of the additional acetoxy group. The similar NOE correlations of $\mathbf{9}$ and $\mathbf{1 1}$ suggested that they shared the same configuration. Thus, compound $\mathbf{9}$ was elucidated as 8-O-acetyl analogue of falconensin I (11).

The specific optical rotation values of $\mathbf{1}, \mathbf{2}, \mathbf{7}, \mathbf{8}$, and 9 are positive $(+99-+233)$, which is in agreement with the positive values reported for other known falconensin derivatives with $7 R, 8 S$, and $8 \mathrm{a} S$ configuration, suggesting that the new compounds share the same absolute configuration as the known derivatives $[18,20,25]$. Although the absolute configuration of other falconensin derivatives had been determined previously by Mosher's reaction and observation of Cotton effects of CD curves $[18,20,25]$, no crystal structure had so far been reported for these compounds. To independently assign the absolute configuration of the isolated compounds, a single crystal X-ray diffraction analysis through anomalous dispersion of the known falconensin N (5), for which crystals of sufficient quality were obtained, was conducted. Herein, we present for the first time the crystal structure of falconensin N (5) (Figure 2). From the single-crystal structure refinement, the absolute structure assignment was based on the Flack parameter of 0.016(5) (Table S1) [26-29]. The crystal structure of falconensin N (5) is in agreement with the previously reported absolute configuration $[18,20,25]$. Based on these data, all falconensin derivatives isolated in this study are suggested to share the same $7 R, 8 S$, and $8 \mathrm{a} S$ absolute configuration.

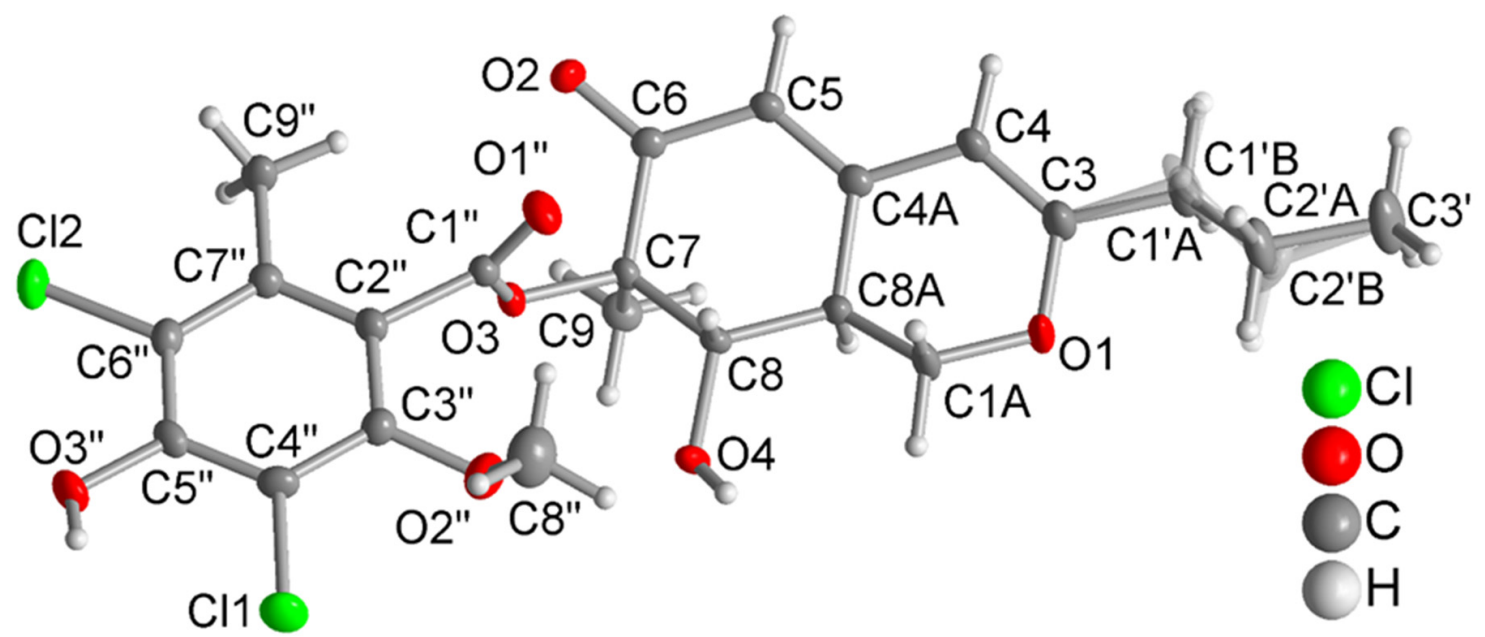

Figure 2. Molecular structure of 5 from a single-crystal X-ray structure determination (50\% thermal ellipsoids; $\mathrm{H}$ atoms with arbitrary radii). The propyl group is disordered, and the two respective atom positions were refined with equal occupation factors.

Azaphilones constitute a class of fungal metabolites possessing various biological activities, including antiviral, antibacterial, antioxidant, hypolipidemic, cytotoxic, and anti-inflammatory properties [24,30]. For falconensins in particular, anti-inflammatory activity against 12-O-tetradecanoylphorbol-13-acetate-induced inflammatory ear edema in mice had been reported [21]. Compounds 1, 3-9, and $\mathbf{1 1}$ were evaluated for their anti-inflammatory activity in the triple negative breast cancer cell line NF-KB-MDA-MB-231. The $\mathrm{IC}_{50}$ values were calculated based on inhibition of the NF-kB-dependent luciferase activity and revealed NF- $k B$ blockade for all compounds (Table 3). To exclude that cytotoxicity caused reduction of NF- $\mathrm{KB}$ activity, cell viability was determined in parallel. Compounds 1, 4-7, 9, and 11 did not influence cell viability within the selected concentration range, whereas compound 8 reduced cell viability with an $\mathrm{IC}_{50}$ of $126.8 \pm 5.4 \mu \mathrm{M}$, thus showing about 
9-times higher potency in NF-kB-blockade compared to its cytotoxicity. Compound 3 with an $\mathrm{IC}_{50}$ of $89.7 \pm 9.1 \mu \mathrm{M}$ in the cytotoxicity assay only showed around 2-times higher potency in NF-kB-blockade. Plotting the $\mathrm{pIC}_{50}$, which is calculated as the negative decadic logarithm of $\mathrm{IC}_{50}$, of the cell viability against the $\mathrm{pIC}_{50}$ of NF- $\mathrm{BB}$ inhibition, illustrates a greater anti-inflammatory potential of the examined compounds compared to their cytotoxic potential (Figure S40). In conclusion, inhibition of NF- $\mathrm{kB}$ signaling in the TNBC cell line MDA-MB-231 could be induced by $\mathbf{1}, \mathbf{3}-\mathbf{9}$, and $\mathbf{1 1}$, with $\mathbf{7}$ being the most potent compound.

Table 3. $\mathrm{IC}_{50}$ values $(\mu \mathrm{M})$ of the compounds tested in MDA-MB-231 cells for NF- $\mathrm{B}$ inhibition and inhibition of cell viability. ${ }^{\text {a }}$

\begin{tabular}{ccc}
\hline Compound & NF-кB inhibition & Cell viability inhibition \\
\hline Falconensin O (1) & $15.7 \pm 0.7$ & $>200$ \\
Falconensin A (3) & $53.2 \pm 21.4$ & $89.7 \pm 9.1$ \\
Falconensin M (4) & $56.5 \pm 8.3$ & $>200$ \\
Falconensin N (5) & $71.0 \pm 7.3$ & $>200$ \\
Falconensin H (6) & $72.0 \pm 28.1$ & $>400$ \\
Falconensin Q (7) & $11.9 \pm 2.1$ & $>200$ \\
Falconensin R (8) & $14.6 \pm 1.7$ & $126.8 \pm 5.4$ \\
Falconensin S (9) & $20.1 \pm 5.6$ & $>200$ \\
Falconensin I (11) & $19.5 \pm 2.5$ & $>400$ \\
\hline
\end{tabular}

a Average $\mathrm{IC}_{50}$ of at least three individual experiments \pm SD tested in the concentration range of $400 \mu \mathrm{M}$ to $0.78 \mu \mathrm{M}$ $(\mathbf{3}, \mathbf{6}$, and $\mathbf{1 1})$ and $200 \mu \mathrm{M}$ to $0.78 \mu \mathrm{M}(\mathbf{1}, \mathbf{4}, \mathbf{5}, \mathbf{7}, \mathbf{8}$, and $\mathbf{9})$ in a two-fold serial dilution.

\section{Materials and Methods}

\subsection{General Experimental Procedures}

Optical rotations were measured using a Jasco P-2000 polarimeter. The compounds were dissolved in optically pure solvents Uvasol ${ }^{\circledR}$ (spectroscopic grade solvents, Merck). 1D and 2D NMR spectra were recorded on Bruker Avance III 300 or 600 or $700 \mathrm{MHz}$ NMR spectrometers (Bruker BioSpin, Rheinstetten, Germany). Low-resolution mass spectra were recorded with an Ion-Trap-API Finnigan LCQ Deca (Thermo Quest) mass spectrometer, while high-resolution mass data were measured on a FTHRMS-Orbitrap (Thermo-Finnigan) mass spectrometer. HPLC analysis was conducted using a Dionex UltiMate-3400 SD with an LPG-3400SD pump coupled to a photodiode array detector (DAD3000RS) and employing a Knauer Eurospher $C_{18}$ analytical column $(125 \times 4 \mathrm{~mm}$ i.d., $5 \mu \mathrm{m})$. Purification of the compounds was performed using semipreparative HPLC on the VWR Hitachi Chromaster HPLC system, 5160 Pump; 5410 UV detector; Eurosphere-100 $\mathrm{C}_{18}, 300 \mathrm{~mm} \times 8 \mathrm{~mm}$ i.d., $10 \mu \mathrm{m}$, Knauer, Germany) with $\mathrm{MeOH}$ and $\mathrm{H} 2 \mathrm{O}$ as eluents utilizing a flow rate of $5 \mathrm{~mL} / \mathrm{min}$. Column chromatography was performed using different stationary phases including Merck MN silica gel $60 \mathrm{M}(0.04-0.063 \mathrm{~mm})$, silica gel $60 \mathrm{RP}-18(40-63 \mu \mathrm{m})$, and Sephadex LH-20 (Merck). TLC plates precoated with silica gel $60 \mathrm{~F}_{254}$ (Merck) were used for monitoring fractions resulting from column chromatography. Detection of spots on the TLC was done by UV absorption at 254 and $365 \mathrm{~nm}$ followed by anisaldehyde spray reagent.

\subsection{Fungal Material}

The fungus was isolated from marine sediment which was collected at a depth of $25 \mathrm{~m}$ from the Canyon at Dahab, Red Sea, Egypt in November 2016. The fungus was identified as A. falconensis (GenBank accession No. MN905375) through amplification and sequencing of the internal transcribed spacer region including the $5.8 \mathrm{~S}$ ribosomal DNA following by a subsequent BLAST search in NCBI as described before [31]. A deep-frozen specimen of the fungal strain has been deposited in one of the author's laboratory (P.P.). 


\subsection{Fermentation, Extraction, and Isolation}

Initial fermentation of the fungus was conducted in ten $1 \mathrm{~L}$ Erlenmeyer flasks. To each flask, $100 \mathrm{~g}$ of rice (Oryza Milchreis), $100 \mathrm{~mL}$ of demineralized water, and $3.5 \mathrm{~g}$ of $\mathrm{NaCl}$ were added. Thereafter, the flasks were autoclaved at $121^{\circ} \mathrm{C}$ for $20 \mathrm{~min}$ and after cooling to room temperature, the fungus was inoculated on the rice medium. Fermentation of the fungus was continued under static conditions for 21 days at $20^{\circ} \mathrm{C}$ until the fungus had totally overgrown the medium. Then, each flask was extracted with 600 mL EtOAc. After overnight soaking in EtOAc, the rice medium was cut into small pieces and shaken for $8 \mathrm{~h}$ at $150 \mathrm{rpm}$ followed by evaporation of EtOAc, yielding around $16 \mathrm{~g}$ of EtOAc extract. For the OSMAC experiment, the same cultivation and extraction procedures of the initial cultivation were conducted except for the replacement of the added $3.5 \% \mathrm{NaCl}$ with $3.5 \% \mathrm{NaBr}$ and the cultivation on three flasks instead of ten. Eventually, the OSMAC experiment yielded approximately $2 \mathrm{~g}$ of EtOAc extract.

The initial crude extract of the large scale cultivation of the fungus obtained in presence of $\mathrm{NaCl}$ (16 g) was fractionated by vacuum liquid chromatography (VLC) on silica gel as a stationary phase utilizing a step gradient of solvents consisting of mixtures of $n$-hexane/EtOAc and $\mathrm{CH}_{2} \mathrm{Cl}_{2} / \mathrm{MeOH}$, to yield 12 fractions (V1 to V12). Fraction V4 (874 mg) was further separated by Sephadex LH20 column chromatography using $\mathrm{CH}_{2} \mathrm{Cl}_{2}-\mathrm{MeOH}$ (1:1) as mobile phase affording eight subfractions (V4-S1 to V4-S8). Subfraction V4-S4 (162.8 mg) was purified by semi-preparative HPLC using acetonitrile- $\mathrm{H}_{2} \mathrm{O}$ containing $0.1 \%$ formic acid (from 60:40 to $95: 5 \mathrm{in} 22 \mathrm{~min}$ ) to afford $\mathbf{1}(1.8 \mathrm{mg}), \mathbf{2}(1.5 \mathrm{mg}$ ), and $\mathbf{3}(11.8 \mathrm{mg})$. Subfraction V4-S5 (139.6 mg) was further purified by semi-preparative HPLC using gradient elution with acetonitrile- $\mathrm{H}_{2} \mathrm{O}$ containing $0.1 \%$ formic acid (60:40 to 95:5 in $22 \mathrm{~min}$ ) affording 4 (6.3 $\mathrm{mg}$ ) and 5 (2.2 mg). Fraction V6 (686.1 mg) was submitted to RP-VLC column using $\mathrm{H}_{2} \mathrm{O}-\mathrm{MeOH}$ gradient elution to yield 10 subfractions (V6-R1 to V6-R10). Subfraction V6-R7 (110 mg) was further purified using semi-preparative HPLC with a gradient of $\mathrm{MeOH}-\mathrm{H}_{2} \mathrm{O}$ containing $0.1 \%$ formic acid (67:33 to 80:20 in $20 \mathrm{~min})$ to afford $6(15.1 \mathrm{mg})$.

The EtOAc extract $(2 \mathrm{~g})$ obtained from the OSMAC experiment with addition of $3.5 \% \mathrm{NaBr}$, was also fractionated by VLC on silica gel as described before to give 13 fractions (BrV1 to BrV13). Subsequent purification of BrV5 (157 mg), BrV6 (32 mg), and BrV10 (140 mg) using Sephadex LH20 column chromatography with $\mathrm{CH}_{2} \mathrm{Cl}_{2}-\mathrm{MeOH}$ (1:1) as mobile phase and semi-preparative HPLC with a gradient of $\mathrm{MeOH}-\mathrm{H}_{2} \mathrm{O}$ containing $0.1 \%$ formic acid to afford $7(3.1 \mathrm{mg}), 8(2.1 \mathrm{mg}), 9(1.2 \mathrm{mg}), 10$ $(0.9 \mathrm{mg})$, and $\mathbf{1 1}(2.0 \mathrm{mg})$.

Falconensin O (1): Yellow oil; $[\alpha]_{D}^{20}+176\left(c\right.$ 0.2, MeOH); UV (MeOH) $\lambda_{\max } 355$ and $206 \mathrm{~nm} ;{ }^{1} \mathrm{H}$ and

${ }^{13} \mathrm{C}$ NMR data, Tables 1 and 2; HRESIMS $m / z 511.0923[\mathrm{M}+\mathrm{H}]^{+}$(calcd for $\left.\mathrm{C}_{24} \mathrm{H}_{25} \mathrm{Cl}_{2} \mathrm{O}_{8}, 511.0921\right)$.

Falconensin P (2): Yellow amorphous powder; $[\alpha]_{D}^{20}+233($ c 0.2, $\mathrm{MeOH}) ; \mathrm{UV}(\mathrm{MeOH}) \lambda_{\max } 329$ and $216 \mathrm{~nm} ;{ }^{1} \mathrm{H}$ and ${ }^{13} \mathrm{C}$ NMR data, Tables 1 and 2; HRESIMS $m / z 513.1073[\mathrm{M}+\mathrm{H}]^{+}$(calcd for $\mathrm{C}_{24} \mathrm{H}_{27} \mathrm{Cl}_{2} \mathrm{O}_{8}$, 513.1077).

Falconensin $Q$ (7): Yellow oil; $[\alpha]_{D}^{20}+182\left(c\right.$ 0.2, MeOH); UV (MeOH) $\lambda_{\max } 354$ and $205 \mathrm{~nm} ;{ }^{1} \mathrm{H}$ and

${ }^{13} \mathrm{C}$ NMR data, Tables 1 and 2; HRESIMS $m / z 479.0702[\mathrm{M}+\mathrm{H}]^{+}$(calcd for $\mathrm{C}_{22} \mathrm{H}_{24} \mathrm{BrO}_{7}, 479.0700$ ).

Falconensin R (8): Yellow oil; $[\alpha]_{D}^{20}+99($ c 0.2, $\mathrm{MeOH}) ; \mathrm{UV}(\mathrm{MeOH}) \lambda_{\max } 353$ and $206 \mathrm{~nm} ;{ }^{1} \mathrm{H}$ and

${ }^{13} \mathrm{C}$ NMR data, Tables 1 and 2; HRESIMS $m / z 493.0853[\mathrm{M}+\mathrm{H}]^{+}$(calcd for $\mathrm{C}_{23} \mathrm{H}_{26} \mathrm{BrO}_{7}, 493.0856$ ).

Falconensin S (9): Yellow oil; $[\alpha]_{D}^{20}+105$ (c 0.2, MeOH); UV (MeOH) $\lambda_{\max } 355$ and $201 \mathrm{~nm} ;{ }^{1} \mathrm{H}$ and

${ }^{13} \mathrm{C}$ NMR data, Tables 1 and 2; HRESIMS $m / z 443.1700[\mathrm{M}+\mathrm{H}]^{+}$(calcd for $\mathrm{C}_{24} \mathrm{H}_{27} \mathrm{O}_{8}, 443.1700$ ).

\subsection{Crystallographic Analysis of Compound $\mathbf{5}$}

Crystals were obtained by solvent evaporation (MeOH). Data Collection: compound 5 was measured with a Bruker Kappa APEX2 CCD diffractometer with a microfocus tube and $\mathrm{Cu}-\mathrm{K} \alpha$ radiation $(\lambda=1.54178 \AA)$. APEX2 was used for data collection, SAINT for cell refinement and data reduction [32], and SADABS for experimental absorption correction [33]. The structure was solved by intrinsic phasing using SHELXT [34], and refinement was done by full-matrix least-squares on $\mathrm{F}^{2}$ using SHELXL-2016/6 [35]. The hydrogen atoms were positioned geometrically (with C-H $=0.95 \AA$ for 
aromatic $\mathrm{CH}, 1.00 \AA$ for aliphatic $\mathrm{CH}, 0.99 \AA$ for $\mathrm{CH}_{2}$, and $0.98 \AA$ for $\mathrm{CH}$ ) and refined using riding models (AFIX 43, 13, 23, 137, respectively), with $\operatorname{Uiso}(\mathrm{H})=1.2 \mathrm{Ueq}\left(\mathrm{CH}, \mathrm{CH}_{2}\right)$, and $1.5 \mathrm{Ueq}\left(\mathrm{CH}_{3}\right)$. The absolute structure configuration of 5 was solved using anomalous dispersion from $\mathrm{Cu}-\mathrm{K} \alpha$, resulting in a Flack parameter of 0.016(5) using Parsons quotient method. All graphics were drawn using DIAMOND [36]. The structural data have been deposited in the Cambridge Crystallographic Data Center (CCDC No. 1976223).

\subsection{Triple Negative Breast Cancer Studies}

\subsubsection{Cell Culture and Chemicals}

Culture medium and supplements were purchased from Gibco (Fisher Scientific, Schwerte, Germany). Cell plates were obtained from Greiner bio-one (Frickenhausen, Germany). Cells were grown and incubated in a humidified $5 \% \mathrm{CO}_{2}$ atmosphere at constant $37^{\circ} \mathrm{C}$. The metastatic breast cancer cell line, MDA-MB-231, was purchased from the European Collection of Authenticated Cell Cultures (ECACC) (Salisbury, UK). Sub-culturing was performed in RPMI 1640 medium (\#21875-034) supplemented with $15 \%(\mathrm{v} / \mathrm{v})$ fetal calf serum (FCS) and 1\% (v/v) penicillin-streptomycin (pen-strep) $(10,000 \mathrm{U} / \mathrm{mL})$. The MDA-MB-231 cell line stably expressing a plasmid with the NF- $\mathrm{kB}$ response element and the gene sequence for the firefly-luciferase protein (NF-KB- MDA-MB-231) was purchased from Signosis (Santa Clara, CA, USA; \#SL-0043). For selection, $100 \mu \mathrm{g} / \mathrm{mL}$ hygromycin B (Life Technologies, Darmstadt, Germany; \#10687010) was applied in high glucose DMEM (\#41966-029) supplemented with $10 \%(\mathrm{v} / \mathrm{v}) \mathrm{FCS}, 1 \%(\mathrm{v} / \mathrm{v})$ pen-strep. Starvation medium for the NF- $\mathrm{KB}$ inhibition assay contained $1 \%(\mathrm{v} / \mathrm{v})$ FCS, $1 \%(\mathrm{v} / \mathrm{v})$ pen-strep, and $100 \mu \mathrm{g} / \mathrm{mL}$ hygromycin B. Cell detachment occurred by trypsinization in $0.25 \%$ trypsin-EDTA and cell counting was performed at 1:1 (v/v) dilution in Erythrosin B (BioCat, Heidelberg, Germany; \#L13002) using the LUNA II automated cell counter (BioCat). Compounds 1, 4, $5,7,8$, and 9 were dissolved in dimethyl sulfoxide (DMSO) to a final concentration of $10 \mathrm{mM}$, whereas the compounds 3, 6, 11 were dissolved at $20 \mathrm{mM}$ in DMSO. Further dilutions in cell culture medium contained maximal $2 \%$ DMSO.

\subsubsection{NF-kB Inhibitory Assay}

$3 \times 10^{4}$ NFKB-MDA-MB-231 cells were seeded in total $100 \mu \mathrm{L}$ medium per well in a 96-well plate (Greiner; \#655098). On the next day, medium was exchanged, and triplicates were pre-incubated for $20 \mathrm{~min}$ without (negative control) or with compounds in total $100 \mu \mathrm{L}$ starvation medium. Final concentration of the compounds ranged a twofold serial dilution starting from $400 \mu \mathrm{M}$ (compound 3, 6, and 11) or $200 \mu \mathrm{M}$ (compound 1, 4, 5, 7, 8, and 9) to $0.78 \mu \mathrm{M}$. To activate NF- $\mathrm{kB}$ signaling, untreated cells (positive control) or compound treated cells were subsequently stimulated for $24 \mathrm{~h}$ with $20 \mathrm{ng} / \mathrm{mL}$ TNF $\alpha$ (Peprotech, Hamburg, Germany; \#300-01A). Finally, cell lysis and measurement were done according to the manufacturer's instruction of the Luciferase Assay System (Promega, Mannheim, Germany; \#E1500). Injection of equal volume of luciferase substrate with $10 \mathrm{~s}$ integration time and subsequent luminescence measurement was performed using the Spark ${ }^{\circledR}$ microplate reader (TECAN, Männedorf, Switzerland).

\subsubsection{Cell Viability Assay}

Using the CyBio ${ }^{\circledR}$ Well vario pipetting robot (Analytik Jena, Jena, Germany; \#OL3381-24-730), $18 \mu \mathrm{L}$ of the MDA-MB-231 cell suspension $\left(2.8 \times 10^{5}\right.$ cells $\left./ \mathrm{mL}\right)$ were seeded per well in a 384-well plate (Greiner; \#781074) and incubated for $24 \mathrm{~h}$. The final concentration of the compounds ranged in twofold serial dilution steps starting from $400 \mu \mathrm{M}$ (compound 3, 6, and 11) or $200 \mu \mathrm{M}$ (compound 1, 4, 5, 7, 8, and 9) to $0.78 \mu \mathrm{M}$. After $24 \mathrm{~h}$ compound stimulation in quadruples, cell lysis and measurement were done as prescribed in the manufacturer's instruction of the CellTiter-Glo ${ }^{\circledR}$ Luminescent Cell Viability Assay (Promega; \#G7570). In short, it was applied equal volume of the CellTiter-Glo ${ }^{\circledR}$ reagent and luminescence was measured using the Spark ${ }^{\circledR}$ microplate reader (TECAN). 


\subsubsection{Statistical Analysis}

Data of the NF-KB inhibitory assay and cell viability assay represent at least three individual experiments and were analyzed using GraphPad Prism (GraphPad Software, San Diego, USA; Version 8.1.2). For the NF- $\mathrm{kB}$ inhibitory assay, data below the relative light unit (RLU) of the negative control were excluded for further analysis. Half maximal inhibitory concentration $\left(\mathrm{IC}_{50}\right)$ values were determined by nonlinear regression analysis based on the dose-response inhibition calculation "log(inhibitor) vs. response-variable slope (four parameters)" without curve fitting.

Supplementary Materials: The following are available online at http://www.mdpi.com/1660-3397/18/4/204/s1, UV, HRMS, 1D and 2D NMR spectra of all the new compounds 1, 2 and 7-9 as well as NF-kB inhibitory potential of the tested compounds and crystal data for compound 5.

Author Contributions: Investigation, D.H.E.-K., F.S.Y., R.H., T.-O.K., C.J., W.L., I.R., and N.T.; writing-original draft preparation, D.H.E.-K.; writing-review and editing and supervision, Z.L. and P.P. All authors have read and agreed to the published version of the manuscript.

Funding: This project was supported by grants of the DFG (GRK 2158, project number 270650915) and the Manchot Foundation to P.P.

Acknowledgments: D.H.E. gratefully acknowledges the Egyptian Government (Ministry of Higher Education) for awarding a doctoral scholarship. Furthermore, we wish to thank Dr. Dent. Abdel Rahman O. El Mekkawi, EFR, PADI IDC staff instructor, founder of I Dive Tribe, Dahab, South Sinai - Egypt, for collecting the sediment sample.

Conflicts of Interest: The authors declare no conflict of interest.

\section{References}

1. Jimenez, C. Marine natural products in medicinal chemistry. ACS Med. Chem. Lett. 2018, 9, 959-961. [CrossRef] [PubMed]

2. Blunt, J.W.; Carroll, A.R.; Copp, B.R.; Davis, R.A.; Keyzers, R.A.; Prinsep, M.R. Marine natural products. Nat. Prod. Rep. 2018, 35, 8-53. [CrossRef]

3. Wang, Y.T.; Xue, Y.R.; Liu, C.H. A brief review of bioactive metabolites derived from deep-sea fungi. Mar. Drugs 2015, 13, 4594-4616. [CrossRef] [PubMed]

4. Fenical, W.; Jensen, P.R.; Cheng, X.C. Halimide, A Cytotoxic Marine Natural Product, and Derivatives Thereof. U.S. Patent No. 6,069,146, 30 May 2000.

5. Petersen, L.E.; Kellermann, M.Y.; Schupp, P.J. Secondary metabolites of marine microbes: From natural products chemistry to chemical ecology. In YOUMARES 9-The oceans: Our Research, our Future; Jungblut, S., Liebich, V., Bode-Dalby, M., Eds.; Springer International Publishing: Cham, Switzerland, 2020; pp. 159-180.

6. Available online: https://www.beyondspringpharma.com/ChannelPage/index.aspx (accessed on 6 November 2019).

7. Zhang, Z.; He, X.; Wu, G.; Liu, C.; Lu, C.; Gu, Q.; Che, Q.; Zhu, T.; Zhang, G.; Li, D. Aniline-tetramic acids from the deep-sea-derived fungus Cladosporium sphaerospermum L3P3 cultured with the HDAC inhibitor SAHA. J. Nat. Prod. 2018, 81, 1651-1657. [CrossRef] [PubMed]

8. Hertweck, C. Hidden biosynthetic treasures brought to light. Nat. Chem. Biol. 2009, 5, 450-452. [CrossRef]

9. Daletos, G.; Ebrahim, W.; Ancheeva, E.; El-Neketi, M.; Lin, W.; Chaidir, C. Microbial co-culture and OSMAC approach as strategies to induce cryptic fungal biogenetic gene clusters. In Chemical Biology of Natural Products; Grothaus, P., Cragg, G.M., Newman, D.J., Eds.; CRC press: Boca Raton, FL, USA, 2017; pp. 233-284.

10. Hofs, R.; Walker, M.; Zeeck, A. Hexacyclinic acid, a polyketide from Streptomyces with a novel carbon skeleton. Angew. Chem. Int. Ed. 2000, 39, 3258-3261. [CrossRef]

11. Zhang, M.; Wang, W.L.; Fang, Y.C.; Zhu, T.J.; Gu, Q.Q.; Zhu, W.M. Cytotoxic alkaloids and antibiotic nordammarane triterpenoids from the marine-derived fungus Aspergillus sydowi. J. Nat. Prod. 2008, 71, 985-989. [CrossRef]

12. Saleem, M.; Ali, M.S.; Hussain, S.; Jabbar, A.; Ashraf, M.; Lee, Y.S. Marine natural products of fungal origin. Nat. Prod. Rep. 2007, 24, 1142-1152. [CrossRef]

13. Ge, H.M.; Yu, Z.G.; Zhang, J.; Wu, J.H.; Tan, R.X. Bioactive alkaloids from endophytic Aspergillus fumigatus. J. Nat. Prod. 2009, 72, 753-755. [CrossRef] 
14. Frank, M.; Ozkaya, F.C.; Muller, W.E.G.; Hamacher, A.; Kassack, M.U.; Lin, W.; Liu, Z.; Proksch, P. Cryptic secondary metabolites from the sponge-associated fungus Aspergillus ochraceus. Mar. Drugs 2019, 17, 99. [CrossRef]

15. El-Kashef, D.H.; Daletos, G.; Plenker, M.; Hartmann, R.; Mandi, A.; Kurtan, T.; Weber, H.; Lin, W.; Ancheeva, E.; Proksch, P. Polyketides and a dihydroquinolone alkaloid from a marine-derived strain of the fungus Metarhizium marquandii. J. Nat. Prod. 2019, 82, 2460-2469. [CrossRef] [PubMed]

16. Kuppers, L.; Ebrahim, W.; El-Neketi, M.; Ozkaya, F.C.; Mandi, A.; Kurtan, T.; Orfali, R.S.; Muller, W.E.G.; Hartmann, R.; Lin, W.H.; et al. Lactones from the sponge-derived fungus Talaromyces rugulosus. Mar. Drugs 2017, 15, 359. [CrossRef] [PubMed]

17. Samson, R.A.; Visagie, C.M.; Houbraken, J.; Hong, S.B.; Hubka, V.; Klaassen, C.H.; Perrone, G.; Seifert, K.A.; Susca, A.; Tanney, J.B.; et al. Phylogeny, identification and nomenclature of the genus Aspergillus. Stud. Mycol. 2014, 78, 141-173. [CrossRef]

18. Itabashi, T.; Nozawa, K.; Miyaji, M.; Udagawa, S.; Nakajima, S.; Kawai, K. Falconensins A, B, C, and D, new compounds related to azaphilone from Emericella falconensis. Chem. Pharm. Bull. 1992, 40, 3142-3144. [CrossRef]

19. Itabashi, T.; Nozawa, K.; Nakajima, S.; Kawai, K. A new azaphilone, falconensin H, from Emericella falconensis. Chem. Pharm. Bull. 1993, 41, 2040-2041. [CrossRef]

20. Itabashi, T.; Ogasawara, N.; Nozawa, K.; Kawai, K. Isolation and structures of new azaphilone derivatives, falconensins E-G, from Emericella falconensis and absolute configurations of falconensins A-G. Chem. Pharm. Bull. 1996, 44, 2213-2217. [CrossRef]

21. Yasukawa, K.; Itabashi, T.; Kawai, K.; Takido, M. Inhibitory effects of falconensins on 12-O-tetradecanoylphorbol-13-acetate-induced inflammatory ear edema in mice. J. Nat. Med. 2008, 62, 384-386. [CrossRef]

22. Agrawal, A.K.; Pielka, E.; Lipinski, A.; Jelen, M.; Kielan, W.; Agrawal, S. Clinical validation of nuclear factor kappa B expression in invasive breast cancer. Tumour Biol. 2018, 40. [CrossRef]

23. Ogasawara, N.; Kawai, K.I. Hydrogenated azaphilones from Emericella falconensis and E. fruticulosa. Phytochemistry 1998, 47, 1131-1135. [CrossRef]

24. Gao, J.M.; Yang, S.X.; Qin, J.C. Azaphilones: Chemistry and biology. Chem. Rev. 2013, 113, 4755-4811. [CrossRef]

25. Huang, H.; Wang, F.; Luo, M.; Chen, Y.; Song, Y.; Zhang, W.; Zhang, S.; Ju, J. Halogenated anthraquinones from the marine-derived fungus Aspergillus sp. SCSIO F063. J. Nat. Prod. 2012, 75, 1346-1352. [CrossRef]

26. Flack, H.D. On enantiomorph-polarity estimation. Acta Crystallogr. Sect. A 1983, 39, 876-881. [CrossRef]

27. Flack, H.D.; Bernardinelli, G. Absolute structure and absolute configuration. Acta Crystallogr. Sect. A 1999, 55, 908-915. [CrossRef] [PubMed]

28. Flack, H.D.; Bernardinelli, G. The use of X-ray crystallography to determine absolute configuration. Chirality 2008, 20, 681-690. [CrossRef] [PubMed]

29. Flack, H.D.; Sadki, M.; Thompson, A.L.; Watkin, D.J. Practical applications of averages and differences of Friedel opposites. Acta Crystallogr. Sect. A 2011, 67, 21-34. [CrossRef]

30. Osmanova, N.; Schultze, W.; Ayoub, N. Azaphilones: A class of fungal metabolites with diverse biological activities. Phytochem. Rev. 2010, 9, 315-342. [CrossRef]

31. Kjer, J.; Debbab, A.; Aly, A.H.; Proksch, P. Methods for isolation of marine-derived endophytic fungi and their bioactive secondary products. Nat. Protoc. 2010, 5, 479-490. [CrossRef]

32. Bruker. Bruker AXS: Apex2, data collection program for the CCD area-detector system; SAINT, data reduction and frame integration program for the CCD area-detector system; Bruker: Billerica, MA, USA, 2014-2015.

33. Sheldrick, G.M. SADABS: Area-Detector Absorption Correction; University of Goettingen: Goettingen, Germany, 1996.

34. Sheldrick, G.M. SHELXT-Integrated space-group and crystal-structure determination. Acta Crystallogr. Sect. A Found. Adv. 2015, 71, 3-8. [CrossRef]

35. Sheldrick, G.M. Crystal structure refinement with SHELXL. Acta Crystallogr. Sect. C Struct. Chem. 2015, 71, 3-8. [CrossRef]

36. Brandenburg, K. Diamond (Version 4), Crystal and Molecular Structure Visualization; Crystal Impact-K, Brandenburg \& H. Putz Gbr: Bonn, Germany, 2009.

(C) 2020 by the authors. Licensee MDPI, Basel, Switzerland. This article is an open access article distributed under the terms and conditions of the Creative Commons Attribution (CC BY) license (http://creativecommons.org/licenses/by/4.0/). 